\title{
Phosphorus removal from greywater in an experimental hybrid compact filter system
}

\author{
K. Kasak ${ }^{1}$, K. Karabelnik ${ }^{1}$, M. Kõiv ${ }^{1,2}$, P. D. Jenssen ${ }^{3}$ \\ \& Ü. Mander ${ }^{1}$ \\ ${ }^{I}$ Department of Geography, Institute of Ecology and Earth Sciences, \\ University of Tartu, Estonia \\ ${ }^{2}$ Department of Civil, Geological and Mining Engineering, \\ Ecole Polytechnique de Montréal, Canada \\ ${ }^{3}$ Department of Mathematical Sciences and Technology, \\ Norwegian University of Life Sciences, Norway
}

\begin{abstract}
The aim of this paper is to analyse phosphorus $(\mathrm{P})$ removal from greywater in an experimental hybrid compact filter system. The potential of a large number of substrates for the removal of phosphorus in greywater has been reviewed. These substrates mainly consist of natural materials, industrial by-products and manmade products. In this study we analyzed the potential effectiveness of $\mathrm{P}$ removal in different filter materials such as industrial by-products (hydrated calcareous oil-shale ash from Estonian thermal power plants) and man-made products (Filtralite ${ }^{\circledR}$ and Filtralite- $\mathrm{P}^{\circledR}$ ). Household greywater consists of wastewater from kitchens, showers and laundry facilities. The reduction of total $\mathrm{P}$ in the ash filter system was up to $95 \%$, achieving a median effluent concentration of $0.56 \mathrm{mg} \mathrm{L}^{-1}$ (median concentration in inflow was $5.1 \mathrm{mg} \mathrm{L}^{-1}$ ), compared to the respective figures of $40-44 \%$ and $2.8-3.3 \mathrm{mg} \mathrm{P} \mathrm{L}^{-1}$ for Filtralite ${ }^{\mathbb{B}}$ systems.

Keywords: constructed wetland, Filtralite, oil-shale ash, phosphorus sorption, subsurface flow filters.
\end{abstract}

\section{Introduction}

Greywater is defined as water that is slightly contaminated by human activities and may possibly be reused after suitable treatment [1]. Greywater usually 
includes water from baths, showers, hand basins, washing machines, dishwashers and kitchen sinks but exclude blackwater from toilets [2, 3]. Greywater constitutes $50-80 \%$ of the total household wastewater [2-4]. It is well known that greywater is less contaminated than blackwater, so purification is much faster, and purified greywater usually has several useful fields of application, such as toilet flushing, garden/crop watering, irrigation, groundwater volume enlargement etc [1,5-7].

Constructed wetlands (CW), especially subsurface flow (SSF) filters, are well suited to greywater treatment $[8,9]$, although further research is required due to the great variation in greywater loading rates and characteristics [3] (Table 1). Greywater composition varies greatly with lifestyle: family size, the age of the residents, eating habits, washing habits, detergents used etc [10]. One option is to design a compact filter system that involves the separate treatment of greywater in a combined filter system, and high loading rates must also be applied.

Table 1: $\quad$ The characteristics of greywater by different categories [3].

\begin{tabular}{|l|c|c|c|c|}
\hline & Bathroom & Laundry & Kitchen & Mixed \\
\hline $\mathrm{pH}$ & $6.4-8.1$ & $7.1-10$ & $5.9-7.4$ & $6.3-8.1$ \\
\hline $\mathrm{TSS}\left(\mathrm{mg} \mathrm{L}^{-1}\right)$ & $7-505$ & $68-465$ & $134-1300$ & $25-183$ \\
\hline $\mathrm{COD}\left(\mathrm{mg} \mathrm{L}^{-1}\right)$ & $100-633$ & $231-2950$ & $26-2050$ & $100-700$ \\
\hline BOD $\left(\mathrm{mg} \mathrm{L}^{-1}\right)$ & $50-300$ & $48-472$ & $536-1460$ & $47-466$ \\
\hline $\mathrm{TN}\left(\mathrm{mg} \mathrm{L}^{-1}\right)$ & $3.6-19.4$ & $1.1-40.3$ & $11.4-74$ & $1.7-34.3$ \\
\hline TP $\left(\mathrm{mg} \mathrm{L}^{-1}\right)$ & $0.11->48.8$ & $0->171$ & $2.9-74$ & $0.11-22.8$ \\
\hline
\end{tabular}

\subsection{Phosphorus}

Phosphorus is an important nutrient, although even slightly elevated concentrations of $\mathrm{P}$ can trigger eutrophication [11]. Greywater normally contains a low level of nutrients (N, P) compared to toilet wastewater [9]. In countries where phosphorus-containing detergents have not been banned, dishwashing and laundry detergents are the main sources of phosphorus in greywater [9]. Average $\mathrm{P}$ concentrations are typically found within the range of $4-14 \mathrm{mg} \mathrm{L}^{-1}$ [2]. In subsurface flow constructed wetlands, phosphorus is mainly adsorbed in filter material or precipitated $[12,13]$.

\subsection{Phosphorus binding capacity}

CWs have shown their ability to remove large amounts of $\mathrm{P}[14,15]$ from wastewater using special filter materials with an enhanced P sorption capacity [16]. Phosphorus sorption efficiency is directly related to filter material grain size, distribution, $\mathrm{pH}$, specific surface area and the content of $\mathrm{Al}, \mathrm{Fe}$, or $\mathrm{Ca}$ ions [17-20]. 


\subsubsection{Filtralite $^{\circledR}$ and Filtralite- $P^{\circledR}$}

Filtralite $^{\circledR}$ is a special filter material for wastewater treatment, particularly Filtralite- $\mathrm{P}^{\circledR}$, which is specially modified for better P sorption [16]. Filtralite- $\mathrm{P}^{\circledR}$ has high $\mathrm{pH}$ (10) and high $\mathrm{Ca}$ and $\mathrm{Mg}$ content [21], which makes it good for $\mathrm{P}$ sorption. Ádám et al. [17] described the P-sorption efficiency in different scales: small-, meso- and full-scale CW. The results were $3887 \mathrm{mg} \mathrm{P} \mathrm{kg}^{-1}, 4500 \mathrm{mg}$ $\mathrm{P} \mathrm{kg}^{-1}$ and $52 \mathrm{mg} \mathrm{P} \mathrm{kg}^{-1}$ respectively. Heistad et al. [22] studied a wastewater treatment system for use in single houses for 3 years. The system performed excellent total $\mathrm{P}$ removal throughout the experiment. The average reduction in the filter system was $99.4 \%[13,22]$.

\subsubsection{Hydrated oil-shale ash}

Kerogenous oil shale used in Estonian thermal power plants is a solid fuel of low energetic value, which after combustion leaves large amounts of ash (45-48\% of dry mass of shale), and Estonian oil-shale is also highly calcareous [12, 13]. Batch experiments by Kaasik et al. [23] indicated the good (up to $65 \mathrm{mg} \mathrm{P} \mathrm{g}^{-1}$ ) P binding capacity of the hydrated oil-shale ash sediment, with a removal effectiveness of $67-85 \%$ [13, 23]. Vohla et al. [12] found a retention capacity of $8.2 \mathrm{~g} \mathrm{P} \mathrm{kg}^{-1}$, which is a lower capacity value, probably due to different methodology and calculation techniques [12, 13]. Liira et al. [20] carried out a laboratory experiment to investigate phosphorus binding capacity at different retention times. The result showed good removal efficiency (up to $91 \%$ at loading of $1.66 \mathrm{~g} \mathrm{P} \mathrm{m}^{-2} \mathrm{~d}^{-1}$ ) in the experiment with the longest retention time. However, chemical clogging by carbonate precipitates probably reduces the availability of $\mathrm{Ca}$ from the dissolution of mineral phases of unstable ash sediment, and phosphate removal decreases rapidly from $91 \%$ to $49 \%$ [20].

The main objective of this study is to determine the treatment capacity of hydrated oil shale ash (an industrial by-product), Filtralite ${ }^{\circledR}$, and Filtralite- $\mathrm{P}^{\circledR}$ in compact highly loaded filter systems, in order to reduce phosphorus concentration in household greywater, which includes water from kitchen sinks and dishwashers.

\section{Materials and methods}

\subsection{Case}

An onsite indoor experiment for the treatment of household greywater has been in operation since October 2009. The study was carried out using samples from a single household's greywater. The household has five residents. The separated greywater piping system collects wastewater from showers, hand basins, a washing machine and the kitchen. 


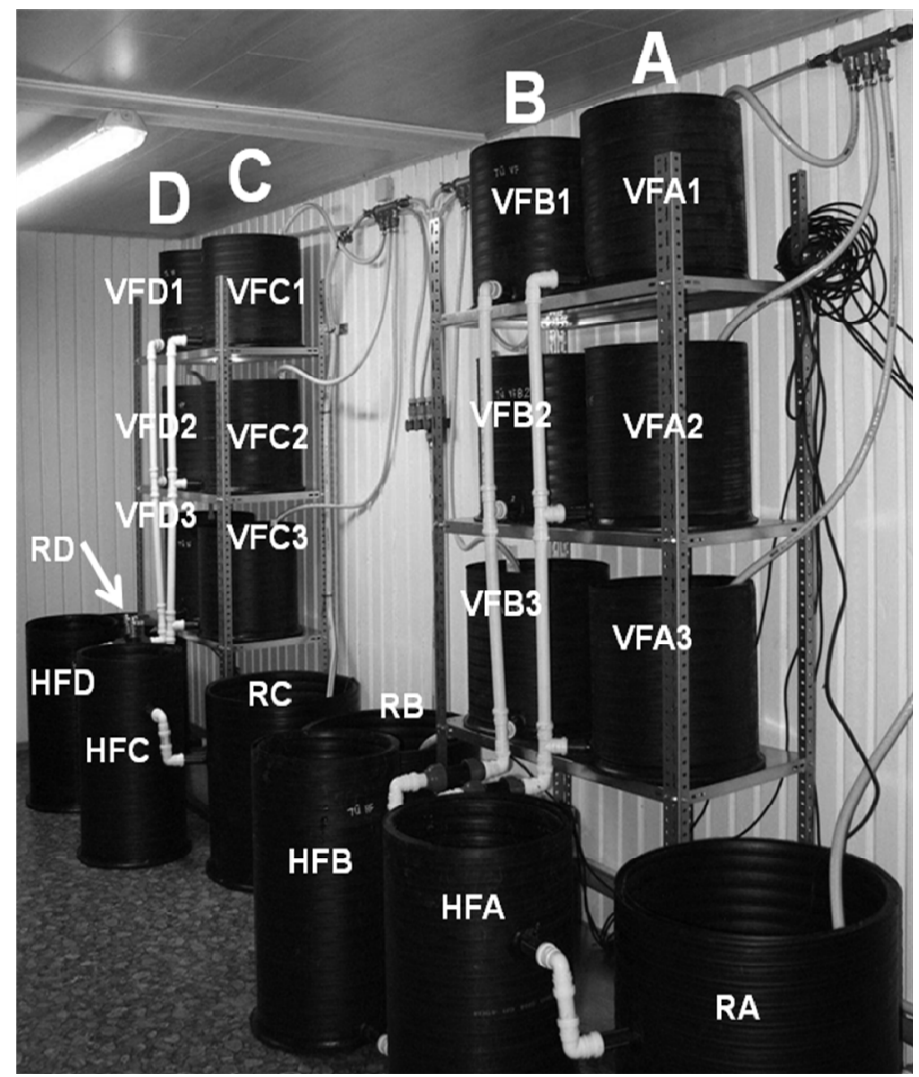

Figure 1: Pilot-scale layout: filter systems A, B, C and D consisting of three vertical flow filters (VF; on shelf) followed by horizontal flow filters (HF; on floor) and re-circulation wells (R; on floor).

\subsection{Description of experimental system}

Experimental pilot-scale hybrid filter systems (A, B, C, D; Fig. 1), each consisting of three parallel vertical flow filters (VF; $0.02 \mathrm{~m}^{3}$ each), are followed by a horizontal flow hydraulically saturated filter (HF; $0.05 \mathrm{~m}^{3}$ ), and those horizontal filters are followed by a recirculation well $\left(\mathrm{R} ; 0,07 \mathrm{~m}^{3}\right)$. The hydraulic loading rate of raw greywater is $32-80 \mathrm{~L} \mathrm{~d}^{-1}\left(100-250 \mathrm{~mm} \mathrm{~d}^{-1}\right)$, with an additional re-circulation rate of $300 \%$, which is 60 cycles per day, equivalent to one dose every 24 minutes. The filter materials are different fractions of Filtralite ${ }^{\circledR}$ in the VF of systems A, B and C (2-4mm round, 4-10mm crushed and 4-10mm round respectively), Filtralite- $\mathrm{P}^{\circledR}$ in the $\mathrm{HF}$ of systems $\mathrm{A}, \mathrm{B}$ and $\mathrm{C}$ in the fraction 0 $4 \mathrm{~mm}$, and alkaline Ca-rich crushed/screened hydrated oil shale ash sediment $(\mathrm{d}=5-20 \mathrm{~mm})$ in the VF and HF of system D. Raw greywater is first depurated in a settling tank $\left(2 \mathrm{~m}^{3}\right)$ and then led to the collection well $\left(0.4 \mathrm{~m}^{3}\right)$, which is 
located in the test house. Then the pump in the collection well divides greywater to each system in equal parts.

\subsection{Operational periods, sampling and water analysis}

This experiment has been divided into 3 periods: the first period represents results from October 2009 to February 2010. In addition, results from 01.12.2009 - 22.12.2009 are not correct due to the inflow problem: blackwater and greywater were accidentally mixed. The second period started on February 2010, when system $\mathrm{C}$ was switched off due to poor purification effectiveness. Thereafter, the total hydraulic loading rate increased from $32.5 \mathrm{~L} \mathrm{~d}^{-1}$ to $80 \mathrm{~L} \mathrm{~d}^{-1}$ (Table 2). Finally, the third period began from June 2010, when the household started to use phosphorus-free detergents. Hydraulic loading rates in the third period were the same as in the second period. From April 2010 no further samples from system A were taken due to the non-satisfactory performance of the filter material, although the system is still running.

Water samples from 10 sampling points were taken regularly. The raw greywater samples were collected from the primary settling tank. Samples from the test plant were taken from the collection well, the outflow from vertical flow filters and the outflow from horizontal flow filters, which also make up the system's outflow. Five analyses were carried out on site: pH (also in the laboratory), temperature, oxygen concentration, dissolved oxygen and conductivity, which were all taken using a portable device (WTW Multi 350i). For the remaining parameters, samples were stored in a thermal box before being transported to the laboratory.

Table 2: $\quad$ System layout, flow regime, operational characteristics.

\begin{tabular}{|l|c|c|c|}
\hline Parameter & Unit & $\begin{array}{c}\text { Period 1 } \\
\text { (Oct. 2009- } \\
\text { Feb. 2010) }\end{array}$ & $\begin{array}{c}\text { Period 2 } \\
\text { (Feb.-June } \\
2010)\end{array}$ \\
\hline Number of parallel systems & - & 4 & 3 \\
\hline Total hydraulic loading rate & $\mathrm{L} \mathrm{d}^{-1}$ & 32.5 & 80 \\
\hline Hydraulic loading of VF filter & $\mathrm{mm} \mathrm{d}^{-1}$ & 104 & 256 \\
\hline Number of cycles & $\mathrm{cyc} \mathrm{d}^{-1}$ & 20 & 40 \\
\hline Length of cycle & $\mathrm{sec}$ & 15 & 12 \\
\hline Re-circulation rate & $\%$ & 300 & 300 \\
\hline Number of re-circulation cycles & cyc d & 60 & 120 \\
\hline Length of re-circulation cycle & $\mathrm{sec}$ & 15 & 15 \\
\hline
\end{tabular}

In the water samples, $\mathrm{BOD}_{7}, \mathrm{COD}$, total nitrogen (TN), $\mathrm{NH}_{4}-\mathrm{N}, \mathrm{NO}_{3}-\mathrm{N}, \mathrm{NO}_{2^{-}}$ $\mathrm{N}$, total phosphorus (TP), $\mathrm{PO}_{4}$ and $\mathrm{pH}$ were determined in a certified Tartu Environmental Research Ltd. Laboratory using standard methods [24]. In this paper only phosphorus has been taken into consideration. 


\section{Results and discussion}

In the first period (October 2009-February 2010), the reduction of TP in the ash filter system was up to $95 \%$, achieving a median effluent concentration of 0.56 $\mathrm{mg} \mathrm{L}^{-1}$ (median concentration in the inflow was $5.1 \mathrm{mg} \mathrm{L}^{-1}$ ) compared to the respective $40-44 \%$ and $2.8-3.3 \mathrm{mg} \mathrm{P} \mathrm{L}^{-1}$ for the Filtralite ${ }^{\circledR}$ systems (Fig. 2). In the second period (February 2010-June 2010) the reduction of TP in the ash filter system was up to $90 \%$, achieving a median effluent concentration of $1.50 \mathrm{mg} \mathrm{L}^{-1}$ (median concentration in inflow was $9.5 \mathrm{mg} \mathrm{L}^{-1}$ ) compared to the respective $39-46 \%$ and $6.3-7.0 \mathrm{mg} \mathrm{P} \mathrm{L}^{-1}$ for the Filtralite ${ }^{\circledR}$ systems (Fig. 2). In the third period (which began in June 2010), the household started to use P-free detergents, and then the inflow $\mathrm{P}$ concentration decreased remarkably. It is evident that purification efficiencies were slightly different in Filtralite ${ }^{\circledR}$ systems, but the performance of the oil-shale ash system was considerably better (Fig. 2). Regarding the oil-shale ash, the results indicate that under cold water temperature (median $8^{\circ} \mathrm{C}$ ) and high $\mathrm{pH}$ (median outflow value 9.3) conditions, the filter system needs a longer starting period to develop a microbial community for biological processes. The high phosphorus sorption potential of hydrated oil shale ash is considered to be due to the high content of reactive Ca-minerals, of which ettringite $\mathrm{Ca}_{6}\left(\mathrm{SO}_{4}\right)_{3}(\mathrm{OH})_{12} \cdot 26 \mathrm{H}_{2} \mathrm{O}$ and portlandite $\mathrm{Ca}(\mathrm{OH})_{2}$ are the most important [23].

The median reduction in the COD value was $85-88 \%$ for Filtralite ${ }^{\circledR}$ systems and $76 \%$ for oil shale ash systems, while the $\mathrm{BOD}_{7}$ value was on average reduced by $86-93 \%$ and $78 \%$ respectively. The removal efficiency of TN was not remarkable, and the median efficiency of Filtralite ${ }^{\circledR}$ systems and the oil shale ash system was $55-65 \%$ and $52 \%$ respectively. Nevertheless, a median outflow concentration of 4.5-5.5 mg N L $\mathrm{mg}^{-1}$ was achieved. Relatively low performance regarding the mineralization of organic material (relatively high $\mathrm{BOD}_{7}$ and $\mathrm{COD}$ values) and $\mathrm{N}$ removal points to the slow development of microfilm on the filter material. Thus additional studies are needed to explain the possibilities for using compact hybrid filter systems with high hydraulic load.

\section{Conclusion}

The oil shale ash filter system performed at a high phosphorus removal capacity, achieving a median effluent concentration of $0.56 \mathrm{mg} \mathrm{L}^{-1}$ and an up to $95 \%$ reduction of total $\mathrm{P}$. In comparison, the Filtralite ${ }^{\circledR}$ filters demonstrated a TP removal efficiency of 40-44\%, and effluent concentrations of $2.8-3.3 \mathrm{mg} \mathrm{P} \mathrm{L}^{-1}$. Since nitrogen removal in the oil shale ash trial was less efficient than in the Filtralite $^{\circledR}$ systems, the position of the $\mathrm{P}$ removal unit in the compact hybrid system's outline needs to be clarified in the course of further experiments. 

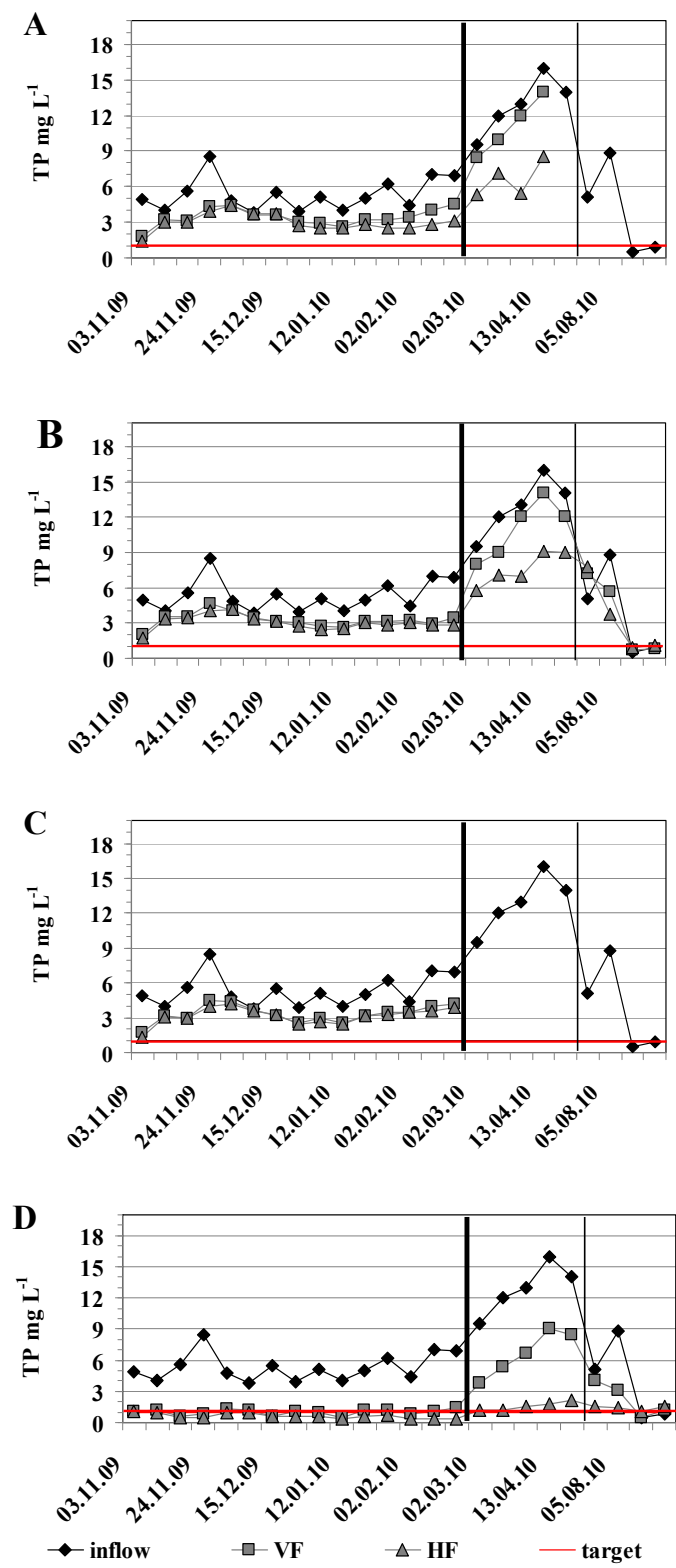

Figure 2: Dynamics of total phosphorus (TP) removal in filter systems. VF vertical flow filter outflow, HF - horizontal flow filter outflow. The target line indicates the legislated standard outflow value $(1 \mathrm{mg}$ $\mathrm{P} \mathrm{L}^{-1}$ ) [25]. The thicker vertical line represents the end of the first period, and the thinner vertical line indicates the beginning of the third period. 


\section{Acknowledgements}

The study was conducted in a research project supported by the EU $7^{\text {th }}$ Framework project No 232274 "SANBOX - Development of an innovative sanitation and wastewater treatment system for remote located tourist facilities". Financial support was also provided by Target Funding Project No. SF0180127s08 of the Ministry of Education and Science of Estonia.

\section{References}

[1] Liu, S., Butler, D., Memon, F.A., Makropoulos, C., Avery, L. \& Jefferson, B., Impacts of residence time during storage on potential of water saving for grey water recycling system. Water Research, 44, pp. 267-277, 2010.

[2] Eriksson, E., Auffarth, K.P.S., Henze, M., Ledin, A., Characteristics of grey wastewater. Urban Water, 4, pp. 85-104, 2002.

[3] Li, F., Wichmann, K. \& Otterpohl, R., Review of the technological approaches for grey water treatment and reuses. Science of the Total Environment, 407, pp. 3439-3449, 2009.

[4] Al-Jayyousi, O.R., Greywater reuse: towards sustainable water management. Desalination, 156, pp. 181-192, 2003.

[5] Eriksson, E., Andersen, H.R., Madsen, T.S. \& Ledin, A., Greywater pollution variability and loadings. Ecological Engineering, 35, pp. 661-669, 2009.

[6] Finley, S., Barrington, S. \& Lyew, D., Reuse of domestic greywater for the irrigation of food crops. Water Air and Soil Pollution, 199, 235-245, 2009.

[7] Friedler, E. \& Hadari, M., Economic feasibility of on-site greywater reuse in multi-storey buildings. Desalination, 190, pp. 221-234, 2006.

[8] Jenssen, P.D. \& Vråle, L., Greywater treatment in combined biofilter/constructed wetlands in cold climate. Ecosan - Closing the Loop. Proc. 2nd Int. Symp. Ecological Sanitation, Lübeck Apr. 7-11. 2003, eds. Werner et al., GTZ: Germany, pp. 875-881, 2003.

[9] Morel, A. \& Diener, S., Greywater Management in Low and MiddleIncome Countries. Review of different treatment systems for households or neighbourhoods. Sandec (Water and Sanitation in Developing Countries at Eawag (Swiss Federal Institute of Aquatic Science and Technology), 107 pp., 2006.

[10] Rasmussen, G., Jenssen, P.D. \& Westlie, L. Graywater treatment options. Recycling the Resource: Proc. 2nd Int. Conf. Ecological Engineering for Wastewater Treatment, Waedenswil, Switzerland, Sept. 18-22 1995, Env. Research Volumes 5-6, eds. Staudenmann, et al., Trans Tech Publications: Stafa-Zürich, Switzerland, pp. 215-220. 1996.

[11] Vymazal, J., Brix, H., Cooper, P.F., Haberl, R., Perfler, R. \& Laber, J., Removal mechanisms and types of constructed wetlands. Constructed Wetlands for Wastewater Treatment in Europe, eds. Vymazal, J., Brix, H., Cooper, P.F., Green, M.B. \& Haberl, R., Backhuys Publishers: Leiden, The Netherlands, pp.11-60, 1998. 
[12] Vohla, C., Põldvere, E., Noorvee, A., Kuusemets, V. \& Mander, Ü., Alternative filter media for phosphorus removal in a horizontal subsurface flow constructed wetland. Journal of Environmental Science and Health A, 40, pp. 1251-1264, 2005.

[13] Vohla, C., Kõiv, M., Bavor, J.H., Chazarenc, F. \& Mander, Ü. 2011. Filter materials for phosphorus removal from wastewater in treatment wetlands A review. Ecological Engineering, 37, pp. 70-89, 2011.

[14] Kadlec, R.H. \& Knight, R.L.. Treatment Wetlands. CRC Press/Lewis Publishers: New York, 893 pp., 1996.

[15] Jenssen, P.D., Mæhlum, T., Krogstad, T. \& Vråle, L., High Performance Constructed Wetlands for Cold Climates. Journal of Environmental Science and Health, 40, pp. 1343-1353, 2005.

[16] Ádám, K., Søvik, A.K. \& Krogstad, T., Sorption of phosphorous to Filtralite- $\mathrm{P}^{\mathrm{TM}}$ - The effect of different scales. Water Research, 40, pp. 11431154, 2006.

[17] Khadhraoui, M., Watanabe, T. \& Kuroda, M., The effect of the physical structure of a porous Ca-based sorbent on its phosphorus removal capacity. Water Research, 36, pp. 3711-3718, 2002

[18] Molle, P., Liénard, A., Grasmick, A., Iwema, A. \&, Kabbai, A., Apatite as an interesting seed to remove phosphorus from wastewater in constructed wetlands. Water Science and Technology, 51, pp. 193-203, 2005.

[19] Ádám, K., Krogstad, T., Vråle, L., Søvik, A.K. \& Jenssen, P.D., Phosphorus retention in the filter materials shells and Filtralite $\mathrm{P}^{\circledR}-$ Batch and column experiment with synthetic $\mathrm{P}$ solution and secondary wastewater. Ecological Engineering, 29, pp. 200-208, 2007.

[20] Liira, M., Kõiv, M., Mander, Ü., Mõtlep, R., Vohla, C. \& Kirsimäe, K., Active filtration of phosphorus on Ca-rich hydrated oil shale ash: does longer retention time improve the process? Environmental Science and Technology, 43, pp. 3809-3814, 2009.

[21] Jenssen, P.D \& Krogstad, T. 2003 Design of constructed wetlands using phosphorus sorbing lightweight aggregate (LWA). Constructed Wetlands for Wastewater Treatment in Cold Climates. International Series on Advances in Ecological Sciences, Vol. 11, eds. Mander, Ü. \& Jenssen, P.D. WIT Press, Southampton, UK, pp. 259-271, 2003.

[22] Heistad, A., Paruch, A.M., Vråle, L., Ádám, K. \& Jenssen, P.D., A Highperformance compact filter system treating domestic wastewater. Ecological Engineering, 28, pp. 374-379, 2006.

[23] Kaasik, A., Vohla, C., Mõtlep, R., Mander, Ü. \& Kirsimäe, K., Hydrated calcareous oil-shale ash as potential filter media for phosphorus removal in constructed wetlands. Water Research, 42, pp. 1315-1323, 2008.

[24] APHA, Standard Methods for the Examination of Water and Wastewater. American Public Health Organisation, 17 $7^{\text {th }}$ edition, Washington, DC, 1989.

[25] Requirements for wastewater discharged into water bodies or into soil. Regulation No. 327 of 19 December 2003 of the Government of the Republic of Estonia, In: RT I 2003.83.565 Tallinn, Estonia, (State Gazette), 2003. (In Estonian). 